\title{
Closing of the One Hundred and Fifty-fourth Academic Year
}

\author{
Armando Mansilla-Olivares \\ Academia Nacional de Medicina, Ciudad de México, México
}

The greatness of the National Academy of Medicine, its incalculable value and indisputable influence manifest themselves in circumstances as simple as the sensation that envelops us just being in its venue, majestic and imposing, which emanates an atmosphere of wisdom, of deep respect, of formality, of seriousness and unwavering commitment to the endless search for knowledge, the analysis of which overflows in abundance, without distrust or pettiness, to the benefit of humanity; an atmosphere that envelops us and evokes our thinking to those who founded it, fostering reasoning, study and creativity within an environment full of respect, freedom, objectivity and tireless struggle to investigate, to scrutinize in the confines of universal knowledge, with the firm intention of finding an explanation and structuring the solution to the problems faced by medical science.

Ladies and gentlemen, members of the National Academy of Medicine, distinguished Doctor José Narro Robles, exemplary academician, ministry of health of the Federal Government and personal representative of the President of the Mexican United States; distinguished members of the head table, honorary academicians, gentlemen former chairmen of the $\mathrm{Na}$ tional Academy of Medicine, heads of department, special and personal guests, members of the Board of Directors.

The National Academy of Medicine is, ladies and gentlemen, the result of much more than a simple directive board or, even, that of the group of all living academicians, but of the group of all its members from its origin to our days. It is precisely them, those who founded this extraordinary institution in 1864, those who illuminated the path where the privileged and exemplary minds that have driven the scientific and humanistic development of medicine in our country have been cultivated. Building upon this premise, I want to emphasize the fact that this presidency wields, with huge respect but with firm conviction, the importance of knowledge from the deepest confines of the atom and the molecule, to the logical and intuitive analysis of the functioning of the body in normal conditions and in pathological state with the purpose to project, with a solid scientific foundation, an effective treatment, according to the patient and the nosological entity that is faced, embedded in a sensibly humanistic context. Hence the masterfully discussed topics in the "Ignacio Chávez" and "Miguel F. Jiménez" conferences throughout this year, whereby molecular knowledge on cell receptor functioning was intertwined with the pathophysiology and treatment of disease. In the same way, next year both conferences will be addressed within the same line, as you will be able to observe in the $155^{\text {th }}$ Academic Year program, which definitely has no match for its content and huge load of knowledge, backed by the intellect of you, who have proposed the topics.

The achievements obtained throughout the $154^{\text {th }}$ Academic Year have definitely been the product of the full disposition, support, solid preparation and the manifestations of respect, sympathy and commitment you have for the National Academy of Medicine. The full report of achievements can be analyzed it in the secretary general report; however, out of gratitude I cannot stop making emphasis on some highlights:

- The Interinstitutional Liaison and Dissemination of Knowledge Committee participated with several presentations in the Chamber of Deputies and issued a position paper in relation to the use of
Date of reception: 09-02-218

Date of acceptance: 15-03-2018

DOI://dx.doi.org/10.24875/GMM.M18000164
Gac Med Mex. 2018;154:350-352

Contents available at PubMed www.gacetamedicademexico.com 
Cannabis sativa, in addition to having another document related to the use of stem cells in process.

- The Ordinary Sessions Dissemination Committee, coordinated by Dr. Mario Mandujano and with the support of a talented team of journalists, makes interviews to the speakers of each session, edits and distributes them through the social networks, including the publication of a brief comment and invitation to them in the Reforma newspaper.

- The Committee of Communication with Schools and Faculties of Medicine, where Dr. Jaime Mas Oliva participates, has spread, through keynote addresses, the importance of the National Academy of Medicine and the work of its members, in the center of the country and in various States of the republic.

- The International Relations Committee narrowed friendship ties with the Society of Latin American Academies of Medicine and dictated two conferences in the City of Bogotá, Colombia.

- The Clinical-Therapeutic Information Committee, the coordinator of which is Dr. Luciano Domínguez, compiled the last two years of work in a volume that has just been distributed.

- The Committee on Ethics and Transparency in the Physician-Industry Relationship (CETREMI), coordinated by Dr. Julio Sotelo Morales, published four position documents.

All this, just to offer some examples.

I cannot help mentioning the enormous effort of Dr. Alejandro Treviño, as editor-in-chief of Gaceta Médica de México, and that of Doctors Miguel Cruz and Francisco Espinosa, who have managed to provide new vigor and a breath of modernity to this publication, without losing sight of the fundamental function of it as a means of communication of the academicians.

In addition, a considerable increase was applied to the economic amount for each one of the prizes that in research, scientific production and transmission of medical thinking the Academy grants year after year. Without neglecting the influence the Academy has exercised through its opinions in the Commission of Science and Technology of the Presidency of the Republic and in the Scientific and Technological Advisory Forum, in collaboration with a group of members of the Institute of Legal Research of the National Autonomous University of Mexico, is currently working on a collegial opinion about the future of social security in our country, with a vision focused on the first level of care, on the training of human resources and scientific research. In addition, nine medical works that go from the recapitulation and update of the history of the National Academy of Mexico, to a book on prenatal nutrition and its impact on brain development are in press.

In addition to all of the above, as a result of the efforts of Dr. Alberto Lifshitz Guinzberg, materializing the Academy's editorial project was achieved for the first time with the online work entitled Thus is Medicine, giving way to the creation of the National Academy of Medicine Publishing House, the headquarters of which will be the space that was previously occupied by CONACEM. Thanks to Dr. Onofre Muñoz initiative, the CONACEM offices and meeting room are being refurbished in the area that was occupied by the Library of the Academy until one year ago.

As an achievement that I consider very special, the Council of National Academies (CAN), has been integrated and consolidated since last June 16 , thanks to the absolute disposition of Dr. José Luis Morán López, Chairman of the Mexican Academy of Surgery, Dr. Jaime Parada, Chairman of the Mexican Academy of Engineering, and to the intervention of a former Chairman of the Mexican Academy of Surgery and current general coordinator of the Advisory Forum of Science and Technology, Dr. José Franco López. The three CAN chairmen traveled in August to the city of Washington, DC, in the United States, to establish a series of commitments with Dr. Marcia K. McNutt, Chairwoman of the National Academy of Sciences, Dr. Victor Dzau, Chairman of the National Academy of Medicine, and Dr. Dan Mote, Chairman of the National Academy Engineering, commitments that are starting to bring their own fruits in the Mexico-North America relationship within the Senate of the Republic: last Monday, November 27 and soon, in the Ordinary Session of Wednesday, February 14 in this Academy, with a lecture delivered by doctor Victor Dzau.

It would have been impossible for me to coordinate with the talent of all academicians without the support and backing of assistant secretary of the Academy, my friend doctor Gabriel Manjarrez Gutiérrez, without the participation of Dr. Fabio Salamanca and my board of directors, without the work accomplished by Mrs. Elizabeth Gutiérrez Ochoa, administrative coordinator of the Academy, without the wonderful ideas and management alternatives that accountant Paola Valencia Yáñez and her work team, Heide Pérez and Gabriela Nava, offered to me; or else, without the responsibility and unlimited dedication of Germán 
Herrera Plata, without the discussions with Miguel Ángel Vázquez Luna, without the patience of Lydia Cornejo and without the coordinated work of Gerardo, Roberto, José Luis Valdez, Andrés Pineda, Mary Carmen Porragas, Alma and all my other collaborators: Xóchitl, Judith, Javier, Miguel Rosas, Araceli and Erika. Thank you very much to all of you and a very special hug to my family for all this and more.
It only remains for me to emphasize that it is for me a reason for pride and enormous privilege belonging to the most noted group of Mexican medical scientists and specialists, whose work and support have contributed to the progress and development of medicine. I reiterate from this rostrum, my permanent commitment and entire service disposition to the National Academy of Medicine. 